\title{
CAETANO VELOSO, "O ESTRANGEIRO": UM BILHETE DE PASSAGEM PARA UMA VIAGEM ESTILÍSTICO-SEMIÓTICA
}

Claudio Artur O. Rei (UERJ)

Resumo: A Estilística não existe para impor normas sobre como deve ser o discurso, isso compete às Retóricas, porque a Estilística não é normativa, não estabelece se a concisão é desejável no discurso, apenas analisa-Ihe determinados usos. Apoiando-se também na Semiótica de Peirce, faz-se uma análise semiótico-estilística na letra de música "O estrangeiro", de Caetano Veloso, além de conceitos filosóficos sobre o que é ser estrangeiro: "devemos admitir que nos tornamos estrangeiros num outro país porque já o somos por dentro?" (KRISTEVA, 1994, p. 22). Nesse sentido, o poético apresenta-se como um feixe de possibilidades significativas, instaurando um processo de semiose ilimitada, principalmente quando se trata de um texto musical polifônico. Baseando-se em Monteiro (1991) e Martins (1997), faz-se uma análise dos efeitos estilísticos presentes nesta letra de música.

Palavras-chave: Estilística; Semiótica; Caetano Veloso; "O estrangeiro".

Abstract: Stylistics does not exist to impose rules about how speech should be, this is a Rhetoric function, because Stylistics is not normative, it does not establish if conciseness is desirable in speech, it only analyses some uses. Basing on Peirce Semiotics, a stylistic-semiotic study about Caetano Veloso lyrics song "O estrangeiro" is taken, beside philosophical concepts about what is to be a foreigner: "Or should one recognize that one becomes a foreigner in another country because one is already a foreigner from within?" (KRISTEVA, 1994, p. 22). In this regard, the poetical presents itself like a significant beam of possibilities, establishing an unlimited semiosis process, mainly when it comes to a polyphonic musical text. Basing in Monteiro (1991) and Martins (1997), a stylistic analysis of effects present in this song lyrics.

Keywords: Stylistics; Semiotics; Caetano Veloso; "O estrangeiro". 


\section{E POR QUÊ CAETANO VELOSO, E NÃO OUTRO?}

Nascido em Santo Amaro da Purificação, Bahia, em 7 de agosto de 1942, Caetano Veloso mostrou, desde cedo, um grande interesse pela música, mesmo sendo apenas, naquela época - infância e adolescência -, um simples ouvinte/ apreciador de programas de rádio (FRANCHETTI; PÉCORA, 1988, p. 15). Seu primeiro interesse, no entanto, foi o cinema, sentia-se atraído pelo Cinema Novo, de Gláuber Rocha, e, começou, então, a escrever críticas de cinema. Nessa época, cursava a cadeira de Filosofia, na Universidade Federal da Bahia e estava engajado nas atividades efervescentes culturalmente por que passava a cidade de Salvador.

Foi justamente nesse turbilhão de atividades culturais em que Caetano mergulhara e tivera os primeiros contatos com a música, tocava violão em bares, em rodas de amigos; um dia, recebeu convite para musicar uma peça de teatro. A partir daí, seu interesse pela composição aguçou e ele começou a inscrever suas letras em festivais da canção: da TV Excelsior, da TV Record etc. Começava, então, a trajetória artística que deixaria as marcas de sua criativa produtividade no quadro musical brasileiro.

Caetano Veloso, no decorrer de sua carreira, passeou em diferentes gêneros musicais em suas letras: do samba 
à rumba. E, em todos esses gêneros, ele se houve com desenvoltura e originalidade, recriando o já criado; descobrindo novos caminhos, tanto em nível musical quanto em nível poético; contribuindo de forma particular para fixar seu nome de forma singular na história da música popular brasileira, ao fazer refletir em seus textos a língua viva do Brasil. Por meio da língua, imprimiu em seus poemas musicais um estilo individual, original, novo.

Essas caraterísticas da obra de Caetano Veloso resultaram da conjugação de quatro elementos - musical, temático, linguístico e poético - que se interligam coesamente formando um estilo próprio do referido cantor; um estilo caetano de dizer da vida. Vemos, portanto, um grande potencial estilístico a ser desvendado na obra de Caetano Veloso. A plurissignificação de suas letras e seu poder de brincar/jogar com as palavras tornam seus textos ricos e instigantes para análise, como veremos em "O estrangeiro", a seguir:

1 O pintor Paul Gauguin amou a luz na Baía de Guanabara

O compositor Cole Porter adorou as luzes na noite dela

A Baía de Guanabara

O antropólogo Claude Lévi-Strauss detestou a Baía de Guanabara 
5 Pareceu-lhe uma boca banguela

E eu menos a conhecera, mais a amara?

Sou cego de tanto vê-la, de tanto tê-la estrela

O que é uma coisa bela?

O amor é cego

10 Ray Charles é cego

Stevie Wonder é cego

E o albino Hermeto não enxerga mesmo muito bem

Uma baleia, uma telenovela, um alaúde, um trem?

Uma arara?

15 Mas era ao mesmo tempo bela e banguela a Guanabara

Em que se passara, passa, passará o raro pesadelo

Que aqui começo a construir, sempre buscando o belo e o Amaro

Eu não sonhei:

A praia de Botafogo era uma esteira rolante de areia branca e óleo diesel

20 Sob meus tênis

E o Pão de Açúcar menos óbvio possível

À minha frente 
Um Pão de Açúcar com umas arestas insuspeitadas

À áspera luz laranja contra a quase não luz quase não púrpura

25 Do branco das areia e das espumas

Que era tudo quanto havia então de aurora

Estão às minhas costas, um velho com cabelos nas narinas

E uma menina ainda adolescente e muito linda

Não olho pra trás mas sei de tudo

30 Cego às avessas, como nos sonhos, vejo o que desejo

Mas eu não desejo ver o terno negro do velho

Nem os dentes quase-não-púrpura da menina

(Pense Seurat e pense impressionista

Essa coisa da luz nos brancos dente e onda

35 Mas não pense surrealista que é outra onda)

Eu ouço as vozes

Os dois me dizem

Num duplo som

Como que sampleados num Sinclavier:

40 “É chegada a hora da reeducação de alguém

Do Pai, do Filho, do Espírito Santo, amém 
O certo é louco tomar eletrochoque

O certo é saber que o certo é certo

O macho adulto branco sempre no comando

45 E o resto ao resto, o sexo é o corte, o sexo

Reconhecer o valor necessário do ato hipócrita

Riscar os índios, nada esperar dos pretos"

$\mathrm{E}$ eu, menos estrangeiro no lugar que no momento

Sigo mais sozinho caminhando contra o vento

50 E entendo o centro do que estão dizendo

Aquele cara e aquela:

É um desmascaro

Singelo grito:

"O rei está nu"

55 Mas eu desperto porque tudo cala frente ao fato de que o rei é mais

[bonito nu

E eu vou e amo o azul, o púrpura e o amarelo

E entre o meu ir e o do sol, um aro, um elo

("Some may like a soft brazilian singer

But I've given up all attempts at perfection")

(VELOSO, 1989) 
"Deus Nosso Senhor depois de recortar as ilhas gregas, de fazer Siena e Florença, veio, em pessoa, criar um dos lugares mais lindos do mundo nessa entrada atlântica que é a baía de Guanabara". (NAVA, Pedro. apud RÓNAI, 1985, p. 423)

Antes de iniciarmos nossa leitura, gostaríamos de situar o contexto de criação deste disco e algumas impressões que Caetano Veloso tem acerca da letra em questão:

Arto Lindsay tinha me proposto produzir um disco meu junto com Peter Schere seu parceiro no Ambitious Lovers. Mas eu já engatilhada a produção do disco Caetano com Guto Graça Mello. Bob Hurvitz, do selo americano Nonesuch, que já tinha feito um disco meu em Nova York (um que leva meu nome, foi gravado em dois dias e trem faixas só com violão ou com um pequeno grupo armado entre os músicos que me acompanhavam no show Uns), queria fazer um outro disco comigo lá. Eu botei os dois em contato. Daí nasceu Estrangeiro. É um disco de que muita gente fala bem. Eu gosto. Acho que pensei o título do disco e daí pensei em escrever a canção. Sempre soube que no titulo do disco o artigo definido não apareceria, mas no da canção, sim. É uma letra bonita. "Ara / ela" - "aro / elo", são um par de rimas interessantes. E a lembrança de Dylan no final tem muita graça. (VELOSO, 2003 , p. 55, grifos do autor) ${ }^{1}$

Apesar do título e da produção norte-americana deste disco, Estrangeiro em muito se distancia da ideia

1 Nas citações, muitas foram escritas anteriormente à reforma ortográfica, optamos pela transcrição com a ortografia vigente. 
de abandono de sua brasilidade, ao contrário, notamos uma revisitação de Caetano às propostas iniciadas no seu Tropicalismo, como bem apontam Lucchesi e Dieguez: "A volta à origem revela-se procedimento consciente, e se concretiza na capa do LP com a reprodução da pintura de Hélio Eichbauer para a montagem de Rei da vela, em 1967" (1993, p. 202, grifo dos autores). A baía de Guanabara, com a sua praia de Botafogo e o Pão-de-Açúcar, todos citados nesta letra de música, também estão presentes no painel de montagem de $O$ rei da vela e reproduzidos na da capa do $L P / C D$.

Como em "Ele me deu um beijo na boca", "O estrangeiro" também apresenta uma estruturação ímpar (é uma letra de música sem estrofação e sem refrão), diferenciando-se de quase todas as outras letras de Caetano Veloso, pois a viagem do eu-lírico pela pluralidade do ser (estrangeiro) se projeta para opinar sobre todas as faces das microrrealidades do olhar (estrangeiro), reunidas nesse texto. Partimos, então, para uma análise sequencial, dos versos.

Os diferentes olhares para a baía de Guanabara iniciam a música. Como se explica essa diferença de olhares? Caetano é levado a pensar o sentido do seu próprio olhar e do olhar estrangeiro: Paul Gauguin (um dos expoentes do movimento 
impressionista) e Cole Porter (compositor popular norteamericano de blues e jazz), ícones-símbolos da pintura e da música, respectivamente, que representam artes com as quais Caetano Veloso é bem íntimo e que amaram a baía de Guanabara, contrapondo-se a Claude Lévi-Strauss, um antropólogo, que a detestou. Esse contraponto pode ser um ícone-índice do desprezo que Caetano sempre manifestou pelo saber acadêmico-formal.

O pintor Paul Gauguin amou a luz na Baía de Guanabara

O compositor Cole Porter adorou as luzes na noite dela
A Baía de Guanabara
O antropólogo Claude Lévi-Strauss detestou a Baía de Guanabara
Pareceu-lhe uma boca banguela

Caetano inicia a letra, elencando algumas personalidades famosas e seus respectivos olhares em relação à baía de Guanabara, visando apenas a enaltecê-la, evidenciando a sua beleza natural. Observemos como Caetano, ao cantar, prolonga, nestes versos inicias, a sílaba ['ba] de Guanabara, como um índice de prazer, ao pronunciá-la. Fonoestilisticamente, a sílaba ['ba] é bastante sugestiva. Formada por uma oclusiva bilabial [b], que "exprime uma 
explosão de surpresa, espanto" (MARTINS, 1997, p. 34) e que tem por base vocálica um [a], cuja sonoridade remete à ideia de "amplitude, iluminação" (MONTEIRO, 1991, p. 101) e "presta-se à transferência para ideias de claridade, brancura, amplidão, alegria etc." (MARTINS, 1997, p. 30); isto é, o olhar das luzes da/na baía de Guanabara é de causar admiração e espanto, seja por luz solar, seja por luz elétrica, seja por luz lunar.

Entretanto, há a negativa desse olhar: o antropólogo Claude Lévi-Strauss detestou a Baía de Guanabara/ pareceuIhe uma boca banguela. Referência contida no livro Tristes trópicos, no qual o antropólogo escreve: "Parece-me que a paisagem do Rio não está à escala das suas dimensões. $O$ Pão de Açúcar e o Corcovado, todos esses locais tão gabados assemelham-se, para o viajante que entra na baía, as raízes de dentes perdidas nos quatro cantos duma boca desdentada" (LÉVI-STRAUSS, 1979, p. 74).

Assim, sob a suspeita desse olhar antropológico, lançado por Lévi-Strauss, cujas luzes não refletem uma visão familiar por parte de Caetano, a dúvida é logo instaurada, levando o eu-lírico ao questionamento:

E eu menos a conhecera, mais a amara?

Sou cego de tanto vê-la, de tanto tê-la estrela 
O que é uma coisa bela?

O amor é cego Ray Charles é cego

Stevie Wonder é cego

E o albino Hermeto não enxerga mesmo muito bem

Afinal, a Baía de Guanabara, com uma luz adorada por um e amada por outro, foi detestada por aqueloutro, porque Ihe parecia uma boca banguela, é também, ao mesmo tempo, o que o eu-lírico menos conhece e mais ama. A baía é a estrela que Ihe ofusca a visão, provocando-lhe, então, cegueira. Bela! Mas o que é uma coisa bela? Como podemos observar, neste momento, o compositor nos induz a um processo de reflexão sobre quão relativo é o conceito de beleza, e como esse conceito vai se estendendo na mesma proporção em que avançamos a leitura do texto musical. Nesse processo, ocorre uma mudança no sentido do olhar, ao mesmo tempo em que o significado do estrangeiro passa a adquirir outros índices e símbolos.

Caetano, no lugar de usar menos a conheci mais a amei, optou por $E$ eu, menos a conhecera mais a amara?, justamente para associar a forma verbal amara com Sto. Amaro, sua terra natal, como veremos mais adiante. No momento, observemos que o eu-lírico constrói o verso com 
uma interrogativa e com os verbos no pretérito mais-queperfeito, embora seja manifesto o emprego do pretérito perfeito nessa construção, empregando uma enálage (emprego de um tempo verbal por outro [REI, 1989, p. 18]). Vejamos o que Lapa nos diz a respeito dessa troca: “[...] todo sucesso que se reproduza em discurso indireto deve levar os verbos no mais-que-perfeito, porque há a noção de dois tempos passados: aquele em que fala ou medita a personagem, e o outro, anterior, em que passam os fatos a que refere" (1991, p. 148).

Entendemos que o texto musical é uma narrativa na qual o compositor inicia expondo opiniões acerca da baía de Guanabara. Nessa perspectiva, apesar de parecer gramaticalmente errado o mais-que-perfeito, tal uso reflete fatos estilísticos, pois pode querer indicar que todas as citações arroladas só foram descobertas depois de Caetano já ter conhecido a baía de Guanabara, isto é, o conhecer e o amar a baía de Guanabara indicam ações anteriores à tomada de conhecimento do que disseram Paul Gauguin, Cole Porter e Lévi-Strauss sobre a baía. Nesse sentido, o efeito estilístico desse uso do mais-que-perfeito fica ainda mais evidente, quando nos perfilhamos mais uma vez a Lapa: "Evocação de um amor passado, que se obstinava 
a perdurar na memória" (1991, p. 150). A escolha pelo mais-que-perfeito torna-se índice dessas formas verbais, e o aspecto interrogativo da frase passa a ser índice das justificativas que estão presentes nos versos seguintes.

Sou cego de tanto vê-la, de tanto tê-la estrela

O que é uma coisa bela?

O paradoxo cego de tanto vê-la se revela como ícone de uma cegueira, como um leve toque de ironia e humor, cuja sustentação se dá pelo uso da epístrofe ("repetição da mesma palavra no fim de versos e frases" [REI, 1989, p. 14]) da palavra cego nos versos seguintes. Todo esse trecho está impregnado de realidade e ludicidade. Partindo de um lugarcomum, a expressão o amor é cego, o eu-lírico, justificando a cegueira de seu amor à baía de Guanabara e respondendo à pergunta $O$ que é uma coisa bela, afirma, elipticamente: "sou cego [de amor] de tanto vê-la". Essa relação entre amor e cegueira parece-nos bem harmônica, em virtude do homeoteleuto presente neste verso (vê-la/ tê-la/ estrela):

A repetição de sons no final das palavras é designada por nomes diversos: homeoteleuto ("final igual"), rima, eco, sem que seja bem precisa a distinção entre os termos.

Uma distinção que parece satisfatória é a seguinte: o homeoteleuto é o aparecimento de uma terminação igual em palavras 
próximas, sem obedecer a um esquema regular, ocorrendo ocasionalmente numa frase ou num verso. O efeito estilístico que oferece é realçar a correlação entre as palavras em que se dá, podendo também, em certos casos, contribuir para a harmonia imitativa. (MARTINS, 1997, p. 40-41)

A escolha por uma rima interna pode ser vista como índice de um sentimento pessoal do eu-lírico que reflete o seu pensamento interior que está alheio às visões adversas à suas. Como se Caetano Veloso quisesse mostrar que, respondendo à pergunta $O$ que é uma coisa bela, a concepção e o conceito de beleza não se restringissem à luz nem à imagem visual, o que seria um contraponto às primeiras personagens citadas no texto musical, visto que estas segundas (todos são músicos, e por isso, presumivelmente, estejam mais aptos a perceber um belo que não é mais mostrado pela luz, mas pelo som). Nesse sentido, ele contesta aqueles que associam o belo à luz.

Ray Charles é cego

Stevie Wonder é cego

E o albino Hermeto não enxerga mesmo muito bem

Fica-nos claro que a beleza para ele é multissensorial, é sinestésica, com diferentes possibilidades de olhares e que também nos conduz a outros olhares: 
Uma baleia, uma telenovela, um alaúde, um trem?

Uma arara?

Mas era ao mesmo tempo bela e banguela a Guanabara

Como a canção se propusesse um olhar de desejo pela liberdade de pensamentos, Caetano expressa, por meio de uma acumulação de imagens, de coisas distintas entre si (o que Leo Spitzer chamaria de "enumeração caótica" [1961, p. 247]), uma colagem de sensações: visuais (baleia/ telenovela/ trem), auditivas (arara/ alaúde/ trem) e gustativas (baleia), reafirmando que seu olhar de beleza não está intrinsicamente ligado à proporcionalidade das formas ou na simetria das coisas, conforme dita a concepção estética da escola clássica. É curioso observar que o substantivo Guanabara está determinado pelo artigo definido, que dá ao substantivo a que se refere "valor de totalidade" (LAPA, 1991, p. 85), levando-nos a pressupor que se trata de algo íntimo ao eu-lírico. Na enumeração dos substantivos, no primeiro verso desse fragmento, temos como determinante o artigo indefinido, cujo valor estilístico, segundo Lapa, "está na imprecisão que dá às representações (serve, pois, para traduzir a indeterminação e o mistério)" (1991, p. 91), sugerindo o desconhecido ou imprevisível. A imprecisão do 
artigo indefinido, na enumeração contrapondo-se à precisão do definido, em relação à Guanabara, implica uma maior indiferença do eu-lírico com os itens arrolados.

Assim, usando um mas, como operador argumentativo, o eu-lírico retoma os versos iniciais do texto musical, cujos olhares se opunham, e reafirma seu olhar: Mas era ao mesmo tempo bela e banguela a Guanabara, utilizando-se mais uma vez do homeoteleuto (bela e banguela), como um recurso estilístico cuja finalidade é exteriorizar o seu pensamento. Sim! A baía de Guanabara é lindamente banguela como o sorriso de um bebê!

Em que se passara, passa, passará o raro pesadelo

Que aqui começo a construir, sempre buscando o belo e o Amaro

Percebemos, nesses versos, que não são apenas os tempos contidos nas experiências acumuladas por Caetano Veloso, como também os espaços por ele percorridos e reagenciados pela memória: o Amaro (de Santo Amaro da Purificação) e a baía de Guanabara. Além disso, por meio desse recurso baseado na reunião dos espaços (Santo Amaro e Rio), o eu-poético está recuperando a travessia artístico-existencial ao longo da qual seu projeto profissional foi estruturado. Parece-nos claro que o Caetano 
de "O estrangeiro" é alguém mais completo, enriquecido pela maturidade, consequência de uma trajetória de quem firmou, com o ato e a experiência de viver, o pacto da radicalidade em prol da autenticidade, num perfeito casamento entre passado e presente e, quiçá, futuro, como no poliptoto ("emprego de um mesmo verbo em diferentes tempos" [REI, 1989, p. 27]) do verso: Em que se passara, passa, passará o raro pesadelo.

Poderíamos entender uma relação temporal tridimensional, entretanto, não o é, pois a linguagem temporal na obra de Caetano é muito mais imediatista, tendendo a um olhar para um eterno presente, duração do momento, como se tudo fosse o aqui e o agora. $O$ raro pesadelo é um índice do que pode estar ocorrendo agora: a baía de Guanabara, sem a sua natureza, pode ficar banguela. Como ficam os atuais problemas ambientais da baía de Guanabara? Porém muitos não querem enxergar os problemas ambientais do Brasil. Esses problemas estão relacionados com a ocupação desordenada feita pelo colonizador, sem qualquer preocupação com o meio ambiente (esgoto, lixo, poluição, desmatamento, aterramento etc.). Esse olhar é entendido, a partir de uma percepção indicial-simbólica da aliteração ("repetição de 
fonemas consonantais" [REI, 1989, p. 8]) do fonema bilabial surdo [p], cuja expressividade "convém à evocação de seres, coisas, atos, qualidades e sentimentos ligados às ideias de força e intensidade" (MARTINS, 1997, p. 34), e do fonema alvelar [r], cuja expressividade traduz uma sensação cinética de "rapidez, tremor" (MONTEIRO, 1991, p. 102).

Entretanto, o eu-lírico não se rende às adversidades. A incomum rima em quiasmo ("figura de linguagem pela qual se repetem palavras invertendo-Ihes a ordem" [REI, 1989, p. 27]) é símbolo dessa resistência: raro pesadelo e belo e Amaro, isto é, Santo Amaro é símbolo de belo e a possível destruição da baía de Guanabara é símbolo de pesadelo. Então, urge o início da construção do conceito de belo representando na lembrança de Santo Amaro.

Santo Amaro da Purificação é uma recorrência na obra de Caetano. Essa insistência tem sua razão de ser que pode ser encontrada no próprio título deste texto musical, que pode ser índice do sentimento de sentir-se estrangeiro, a respeito das coisas que não se ligam à sua terra natal; afinal, Narciso acha feio o que não é espelho.

Lucchesi e Dieguez apontam outra leitura:

O belo e o amargo, positivo e negativo simultaneamente, costuram recordações prazerosas e dolorosas que envolveram 
a construção do sucesso, mas também a realidade angustiante da prisão e seus desdobramentos. Assim, "amaro" é origem, elo, mas contém a face mais amarga traduzida por Caetano em "Acrilírico" (Santo Amar(g)o da Purificação"). Da mesma forma, o positivo e o negativo remetem à dualidade presente no signo-espaço "Baía de Guanabara (1993, p. 204)

Todavia, se interpretássemos Amaro como amargo, ou repugnante, os elementos belo e Amaro encerrariam uma antítese ("figura pela qual se salienta a oposição entre duas ideias ou palavras" [REI, 1989, p. 9]). Mas não é essa a ênfase, nesse contexto, embora a citação anterior traga um exemplo de um olhar negativo para Santo Amaro, porém isso foi em outra música, em outro momento. Não vemos sentido declarar amor às suas raízes e associá-las a um adjetivo tão pouco valorativo.

O eu-lírico continua a denúncia que também se estende à ação predadora contra o espaço, fruto da ganância capitalista, que faz da natureza um espólio para a ampliação desmedida do lucro sob o disfarce pseudo-humanístico da promoção de progresso e felicidade da civilização:

Eu não sonhei:

A praia de Botafogo era uma esteira rolante de areia branca e óleo diesel 
Sob meus tênis

E o Pão de Açúcar menos óbvio possível

À minha frente

Um Pão de Açúcar com umas arestas insuspeitadas

A áspera luz laranja contra a quase não luz quase não púrpura

Do branco das areia e das espumas

Que era tudo quanto havia então de aurora

A letra dessa música é um texto densamente referencial que descreve uma situação muito simples: o eu-lírico caminha pela Praia de Botafogo; no entanto, Caetano, no lugar de usar um discurso indireto, parte para o discurso direto, empregando um catafórico sinal de dois pontos, como índice, para enfatizar que não se trata realmente de um sonho. Numa visão pragmática, poder-se-ia deduzir, sem esforço, que a experiência aqui descrita é fruto da imaginação inventiva do autor. Essa questão entre sonho e realidade é uma preocupação muito comum em rituais de iniciação esotérica - alguns desses rituais ocorrem durante o estado hipnogógico² ("visões que ocorrem na fase inicial do sono, mas que, de fato, não se caracterizam como sonho"). Por

2 Disponível em: https://www.dicionarioinformal.com.br/significado/hipnogógico/2380/. Acesso em 15 jan. 2021. 
essas razões, temos a impressão de que a cena descrita não foi um delírio da imaginação inventiva do eu-poético. Como um artista da palavra, as ideias podem ser fruto de algo que Caetano andou lendo ou que está relatando uma experiência hipnogógica incomum, ou talvez "apenas" pintando, com palavras, uma tela impressionista tridimensional da Baía de Guanabara, a partir do centro. De qualquer forma, a imagem (metáfora) é maravilhosa. As intenções estilísticas da mudança do uso do artigo, como determinantes de Pãode-Açúcar são índices de dualidade: um que é real (artigo definido) e outro que se imagina ou se idealiza (indefinido).

Há, no entanto, outra possibilidade: antes de se chegar ao que realmente queria dizer, o eu-lírico tem a preocupação em situar, a si mesmo e ao leitor/ouvinte, topograficamente (onde ocorre o diálogo que gerou sua indignação e o levou à produção desse texto-denúncia musical), tanto quando descreve um local já conhecido, como quando se posiciona no espaço físico, ao usar os termos: sob meus tênis, à minha frente, às minhas costas etc., tais locuções adverbiais são ícone-índices para mostrar a localidade em que se encontra.

Nesse sentido, observamos que a expressão esteira rolante é um índice-símbolo que nos faz visualizar que o eu-lírico está caminhando em um local estreito. Na praia de 
Botafogo, existe, de fato, um local estreito para caminhar, afinal, há uma ciclovia e um calçadão que vai até a Praia do Flamengo. Além dessa parte estreita, também há espaço para práticas esportivas de areia: vôlei, futebol, futevôlei... Ciclismo, corridas e caminhadas também são realizados, nessa areia branca. A praia de Botafogo estende-se por 700 metros de extensão e é muito famosa por sua vista para o Pão de Açúcar, a Baía de Guanabara e o Morro da Urca retoma-se aqui a citação de Lévi-Strauss e sua impressão de dentes caninos em meio a uma boca banguela. Um belo programa é ir até lá e observar o pôr-do-sol, já que o banho nas suas águas não é permitido, devido à grande poluição do mar local. Óleo diesel aparece, no texto musical, como índice dessa poluição. Ele está pairando sobre o branco e o negro - que são a areia e o óleo diesel -, uma antítese da baía de Guanabara: o natural belo (areia branca) se contrapondo aos efeitos maléficos do homem sobre a natureza (óleo diesel). Mais uma vez, o tom de denúncia se evidencia na letra da música.

O Pão-de-Açúcar, apesar de seus contornos nítidos, não mais parece ser o Pão-de-Açúcar, no meio da aurora ${ }^{3}$ que o ofusca, mesmo com as insuspeitadas arestas que 0

3 s.f. 1. ASTR Claridade que aponta o início da manhã, antes do sol nascer. [...] 3. firm. Cor branca rosada como a do amanhecer. (HOUAISS, 2009, p. 222). 
formam. É o nascimento diário do sol em cuja beleza reside um olhar sinestésico ("sinestesia: mescla de impressões sensoriais numa sentença" [REI, 1989, p. 30]) e que produz a áspera luz laranja que, refletindo no branco das areias $e$ das espumas, gera uma tonalidade bem opaca desse laranja, por isso é uma quase não-luz quase não-púrpura - o laranja é um vermelho imperfeito, é um quase-não-vermelho e, ao mesmo tempo, um quase-branco. Explica-se assim o uso da sinestesia em áspera luz laranja, pois a aspereza indica "o que não é liso e uniforme" (HOUAISS, 2009, p. 201). Essa aurora deslumbrada pelo eu-lírico é uma não uniformidade de cores, o que torna a cena mais espacial ainda: o sol à esquerda, a cidade à direita, o Pão-de-Açúcar à sua frente, um laranja áspero no alto e um opaco no chão, às suas costas. Ainda é interessante ressaltar a rima existente num texto poético com tão poucas rimas - em púrpural espumas/ aurora: é uma rima menos comum, especialmente em textos musicais, pois são toantes, isto é, ocorre apenas a coincidência entre as vogais. E aqui cabe a polissemia de tom, não apenas relacionado aos acordes, ao som, como também às tonalidades das cores envolvidas nas palavras que rimam. O eu-lírico expõe mais uma vez, seu olhar sinestésico para a baía de Guanabara. 
Então, após o eu-lírico se situar e a seu leitor/ouvinte no tempo e no espaço, ele chega ao objetivo, que elipticamente vinha no texto: narrar um diálogo ouvido, nas areias brancas da praia de Botafogo que faz parte da baía de Guanabara:

Estão às minhas costas, um velho com cabelos nas narinas

E uma menina ainda adolescente e muito linda

Não olho pra trás mas sei de tudo

Cego às avessas, como nos sonhos, vejo o que desejo

Mas eu não desejo ver o terno negro do velho

Nem os dentes quase-não-púrpura da menina

(Pense Seurat e pense impressionista

Essa coisa da luz nos brancos dente e onda

Mas não pense surrealista que é outra onda)

De imediato, percebemos o valor antitético presente nos primeiros versos: velho e adolescente. O eu-poético deixa claro que seu olhar não está na visão, por isso é um cego às avessas, pois o que ele queria ver, como nos sonhos, seria o ensinamento que os mais velhos passam para os mais novos, mas, na verdade, o que ele ouve é exatamente 
o avesso. Um homem velho, de terno negro, com cabelos nas narinas, é apresentado como uma figura exatamente oposta à da menina adolescente, sorridente e muito linda. É outra dualidade: negro e brancos, entretanto, essa antítese é um índice que representa as duas faces da verdade que o eu-lírico desejaria ver, por the parecer o claro e o óbvio. $\mathrm{Na}$ verdade, ele não deseja ver o terno negro do velho (índice de sisudez), nem os dentes quase não-púrpura da menina (índice de sorriso), por isso temos a oposição em quiasmo: vejo o que desejo/ Mas eu não desejo ver, reafirmando a multiplicidade de seu olhar, pois os dentes da menina são brancos, no entanto, tornaram-se alaranjados pelo reflexo luminoso da aurora.

Não nos parece surpresa aparecerem versos entre parêntesis, neste texto musical, uma vez que ele foge ao lugar-comum dos modelos desse gênero textual. Esse destaque, no texto, serve como ênfase para Caetano frisar ao seu leitor/ouvinte que estamos diante de uma cena impressionista. A partir da conscientização dessa realidade, atentemos ao fato de que, na escola impressionista, há duas características marcantes desse movimento da pintura que estão também presentes neste texto musical: 1. Uma manifestação impressionista não é um mero sonho, 
ou um estado hipnogógico, não é criação fantasiosa, mas a percepção subjetiva de uma coisa que realmente existe, o que faz o eu-lírico se posicionar contra aqueles que veem, nessa construção, devaneios do seu inconsciente, pois seria característica do Surrealismo: mas não pense surrealista que é outra onda; 2 . Todo branco da cena está alterado pela luz, como no caso dos dentes e das espumas das ondas. Alterar as cores da realidade é outra característica do Impressionismo, que foi um movimento que surgiu na pintura francesa do século XIX, vivia-se nesse momento a chamada Belle Époque, ou Bela Época, em português. O nome do movimento é derivado da obra "Impressão: nascer do sol" (1872), do pintor Claude Monet, mesmo momento (aurora) em que se dá a experiência do eu-poético.

Sobre essa visão impressionista, gostaríamos de destacar que Georges-Pierre Seurat foi um pintor francês e pioneiro do movimento pontilhista, também chamado divisionismo. A escolha desse pintor impressionista, e não outro, talvez seja essa ideia de organizar e arrumar as coisas por meios de pontos nos lugares certos com suas cores adequadas. $\mathrm{Na}$ coleção Gênios da pintura, no capítulo dedicado a Seurat, temos a seguinte informação:

Seurat, entre todos os neo-impressionistas, foi o único a não ter a sensibilidade asfixiada 
pela rigidez do método. Ao contrário, procurou a forma de reunir o homem fragmentado entre sentimento e razão, emoção e lógica. $E$ se seus personagens aparecem petrificados, hieráticos e já quase abstratos, isso se deve menos à imposição da técnica e mais à poesia trágica que envolve sua angustiada visão da condição humana. (1973, p. 2)

Ainda em relação à técnica de Seurat, encontramos mais à frente: "ao invés de misturar cores, as justapõe, de modo que se conservem puras na tela e se combinem apenas na retina do espectador. Seurat havia lido: 'A cor submetida a regras certas, pode ser ensinada como se ensina música'” (1973, p. 3). Nesse sentido, inferimos que, no Impressionismo, a pintura é uma realidade apreendida pelo olhar. Duarte, comentando a pintura impressionista de Seurat, diz que "para Seurat, o real é a própria pintura" (1993, p. 254), como nos fica claro, mais adiante, na coleção supracitada:

Sua meta era de compor, valendo-se de conhecimentos científicos, uma relação entre percepção visual e efeitos psicológicos no espectador. Seurat integra aquela família de artistas que se inclinam a dissimular sua emotividade, camuflando-a sob a frieza de uma forma precisa, de uma composição refletida. E são quadros como esses, que se contam entre os menos ambiciosos de sua criação, que mostram as virtudes mais 
raras do pintor: uma impalpável delicadeza aliada à autoridade da ordem, a sutileza das vibrações coloridas casada a um desenho ultra-rigoroso. (1973, p. 5, grifo dos editores)

Nesse sentido, pensar Seurat é ter o olhar angustiante da condição humana, mas, ao mesmo tempo, ser capaz de não seguir regras e imposições e ainda conseguir enxergar as cores (que podem ser entendidas como símbolo de muitas coisas) nas tonalidades mais adequadas, por isso a polissemia da palavra onda: na primeira ocorrência, usada como metonímia (a causa pelo efeito, as ondas produzem espumas), o branco servindo para pintar os dentes e as espumas; na segunda ocorrência, como uma gíria popular, significando assunto. Caetano usa a palavra onda como duplo recurso estilístico: além da polissemia, a construção em epístrofe, ou seja, termina os versos com a mesma palavra, no entanto, com intenções distintas. São os muitos olhares impressionistas.

Assim, observamos que o Impressionismo se caracteriza por uma nova maneira de olhar para a realidade e para a pintura, em que esta última é elevada ao status de realidade. É nessa perspectiva que podemos entender a denúncia do eu-lírico, logo em seguida, quando questiona a verdade e a realidade impostas pela tradição, pela ciência, pela igreja e pelo poder ocidental, referidas nos versos entre aspas: 
Eu ouço as vozes

Os dois me dizem

Num duplo som

Como que sampleados num Sinclavier:

“É chegada a hora da reeducação de alguém

Do Pai, do Filho, do Espírito Santo, amém

O certo é louco tomar eletrochoque

O certo é saber que o certo é certo

O macho adulto branco sempre no comando

E o resto ao resto, o sexo é o corte, o sexo

Reconhecer o valor necessário do ato hipócrita

Riscar os índios, nada esperar dos pretos"

Conforme assinalamos anteriormente, esse discurso direto polifônico foi a motivação para Caetano compor esse texto-denúncia. O efeito sonoro das vozes do velho e da menina, falando quase que ao mesmo tempo, é índice do verso como que sampleados ${ }^{4}$ num Sinclavier ${ }^{5}$. Caetano

4 samplear v. (déc. 1980) "1. td. gravar e processar (sons previamente gravados) por meio de um sampleador (s. um dueto com trechos de árias famosas) 2. t.d. montar (composição ou arranjo musical) com uso desse instrumento (s. trecho de árias famosas em ritmo de rock)" (HOUAISS, 2009, p. 1702).

5 "O Sistema Synclavier foi um sintetizador e sampler, fabricado pela New England Digital. Foi lançado originalmente em 1978, e provou ter alta influência tanto entre produtores musicais quanto entre músicos de eletrônica devido à sua versatilidade, som distinto e uma tecnologia 
ouve a conversa e percebe o discurso reacionário implícito no que dizem, expondo-o e denunciando-o. A letra foi escrita em 1989, ano de eleições, Collor venceu Lula, na primeira eleição direta, após o regime militar, e hoje, mais de trinta anos depois, a análise política de Caetano soa muito atual, e isto porque o discurso conservador e reacionário, que permaneceu mais ou menos submerso ao longo das duas últimas décadas, volta a se fazer ouvir, como o próprio Caetano declarou em um depoimento extraído do programa "O que é que a Bahia tem?", para a TVE, em 31 de janeiro de 1992:

"O Estrangeiro" é uma música um pouco sinistra, porque tem todas aquelas linhas de neo-conservadorismo, aquelas falas reacionárias no meio, que são meio terríveis. É um pouco mexer com coisas negativas. Mas, de todo o modo, é uma reflexão sobre as ondas inevitáveis do pensamento no mundo, atualmente. (apud LUCCHESI; DIEGUEZ, 1993, p. 271)

É chegada a hora da reeducação de alguém/ Do Pai, do Filho, do Espírito Santo amém. Na visão dos interlocutores do diálogo, é preciso a reeducação para mudar a situação; entretanto, o eu-lírico se indigna com o ponto de vista, pois o que chamam de reeducação, na verdade, é uma regressão por artistas notórios da indústria da música". (WIKIPEDIA, 2019). Disponível em: https:// pt.wikipedia.org/wiki/Synclavier. Acesso em 16 jan. 2021. 
nos avanços sociais. $E$ as igrejas desempenham um forte papel nisso, por isso a alusão à citação religiosa.

Essa é a visão que o velho e a menina, duas gerações distintas e distantes na idade, passaram para o eu-lírico. Notemos que toda a fala de um deles, pois Caetano não distingue quem fala o quê (vozes sampleadas), foi prefaciada em tom solene, religioso até, visando a ares de revelação bíblica ou de deslumbre e premonição espirituais, como se estivessem profetizando ações que, infelizmente, vieram a se tornar reais: quilombolas tendo seu peso avaliado em arroba, como mercadorias; programas de coquetéis contra o HIV sendo suspensos; demarcações indígenas sendo revogadas etc. Muito pode ser dito acerca do conteúdo dessas palavras: a necessária hipocrisia que permite a convivência social? Essa visão hobbeana faz o eu-poético rejeitar a concordância com elas de modo bastante incisivo. Atentemos ao que nos fala Thomas Hobbes:

Se no tempo, como no espaço, houvesse graus de alto e baixo, acredito firmemente que o mais alto de todos os tempos seria o que transcorreu de 1640 a 1660. Pois quem nele se postasse, como na montanha do Diabo para olhar o mundo e observar as ações dos homens, especialmente na Inglaterra, poderia descortinar um panorama de todas as espécies de injustiça e de todas as espécies de loucura que o mundo possa 
tolerar, e de como foram produzidas pela hipocrisia e vaidade (self-conceit), sendo aquela dobrada iniquidade e esta dupla loucura. (2002, Diálogo I, p. 1)

Desnuda-se, nesses versos, a segregação social provocada pela xenofobia (conceito que abordaremos mais à frente) em que a figura do macho adulto branco é idealizada como o padrão ou segmento social superior aos demais. Poderíamos até acrescentar ao macho adulto branco outras características: escolarizado, rico, politizado, governante etc. Curioso é que esses versos retratam ideia bastante semelhante na música "Podres poderes", de 1984:

Na quarta estrofe, o eu-lírico retorna à sua fala inicial - Enquanto os homens exercem seus podres poderes - mostrando que ocorre uma alienação por parte dos excluídos através do carnaval, pois, ao se mascararem, fogem à exclusão sócio-político-econômica que lhes fora imposta, no decorrer da história da sociedade brasileira. Então, índios, padres, bichas, negros, mulheres e adolescentes fazem o carnaval, porque o poder está nas mãos dos homens brancos, que detêm, em sua maior parte, essa parasitária burocracia estatal e eclesiástica oriunda da colonização ibero-americana. Assim, índios e negros, grupos raciais minoritários, que até hoje lutam por seus direitos, seriam considerados "castas inferiores" sem direito a opinar sobre as decisões; apenas acatá-las, até mesmo por já terem sido obrigados a uma subserviência escravocrata. Padres e bichas são homens, 
mas não representam o perfil latino de masculinidade, falta-lhes a "macheza", uma vez que os padres representam o perdão, a compreensão e a ponderação dos atos, e as bichas representam o lado feminino do homem, a delicadeza, a reflexão antes da ação. Logo para deter os poderes não se tem necessariamente de ser masculino, tem-se de ser "macho". Mulheres e adolescentes representam a inconstância de humores, a fragilidade, características que não podem ser toleradas no poder, por isso também são excluídos. (REI, 2002, p. 106)

Além disso, após a afirmação do macho branco adulto no poder temos o verso $E$ o resto ao resto, o sexo é o corte, o sexo que reforça toda a exclusão apontada na última citação. Depois do macho adulto, tudo vira resto, mas, mesmo assim, o sexo é o corte: negro, índios e homossexuais são cortados. Fica-nos evidente, então, que o macho branco é o sexo dominante.

Após ouvir todo o diálogo, o eu-lírico vê-se atordoado, sentindo-se estrangeiro e segue caminhando contra o vento - aludindo a uma antiga canção, como índice de um desejo de voltar a atenção para si e refletir o dito.

$\mathrm{E} \mathrm{eu}$, menos estrangeiro no lugar que no momento

Sigo mais sozinho caminhando contra o vento

E entendo o centro do que estão dizendo 
Aquele cara e aquela:

É um desmascaro

Observamos, então, que, depois de captar o sentido da mensagem, ele conclui: É um desmascaro. O item lexical desmascaro é o resultado de uma derivação regressiva verbal, cujo verbo primitivo - desmascarar - apresenta a seguinte possibilidade significativa, segundo Houaiss: "2. fig. revelar(-se) [alguém] tal como é, sem disfarces; mostrar(se) em seu verdadeiro caráter ou identidade" (2009, p. 658). Inferimos que essa concepção de desmascaro é uma resposta, atentemos ao catafórico sinal de dois pontos, para aquele cara e aquela. Outro fato a chamar a nossa atenção é que as personagens deixaram de ser um velho e uma menina, sem suas respectivas adjetivações, e passaram a aquele cara e aquela, como índice de uma neutralização do eu-poético em relação aos interlocutores, isto é, qualquer traço de simpatia desapareceu, após a audição do diálogo reacionário dos dois, embora o distanciamento aos dois já houvesse sido marcado, na apresentação deles, pelo uso do artigo indefinido, a imprecisão estabelecida pelo artigo é índice de desconhecimento das pessoas. Afinal, a proposta deles dessa reeducação do olhar que põe em dúvida a certeza das verdades preestabelecidas acaba se 
tornando o ponto catártico e nevrálgico desta composição que leva o eu-poético à descoberta e ao questionamento interior: E eu menos estrangeiro no lugar que no momento. O estrangeiro, nesse contexto, mais do que o resultado de uma distância espacial constitui-se uma distância social ou psicológica provocada pelo momento, pelo tempo.

Segundo Cunha, etimologicamente, estrangeiro é "de, ou relativo à nação diferente daquela a que se pertence" (1997, p. 333). No entanto, quando lemos "estrangeiro", não significa necessariamente uma pessoa que veio de outro país. Há outros olhares para a palavra, outros significados, podendo ser alguém que se vê estranho em sua própria casa, cidade, país ou, até mesmo, em seu próprio planeta, pois se vê num centro que muito se distancia da sensação momento-espaço. Um olhar estrangeiro para si mesmo desemboca no estranhamento de sua própria vida (cabendo, também, nesse olhar, o conceito de infamiliar, de Freud $^{6}$ ) e essa profunda sensação de estranhamento do mundo, assombrada pelas questões mais fundamentais humanas, leva o homem a um autoquestionamento: "Onde estou?", "Quem sou eu?", levando o ser a um sentimento de xenofobia (aversão a estrangeiros) de si mesmo.

\footnotetext{
6 "Não há nenhuma dúvida de que [o infamiliar] diz respeito ao aterrorizante, ao que suscita angústia e horror" (FREUD, 2019, p. 23).
} 
Então, seguindo essa linha de pensamento, quando a consciencialização do ser mergulha profundamente no seu âmago interior, trazendo à tona seu significado de mundo, não existe mais uma casa específica, existe um corpo andarilho no espaço vazio, uma perda, parcial ou integral, do sentido de ser no mundo. Logo, o estrangeiro passa a ser aquele que não sabe qual o sentido tomar, pois nunca passou por aquele caminho. O estrangeiro, por não conhecer aonde ir, está/é livre. Mas a liberdade é a sensação de um corpo atirado no espaço sideral, sem chão, sem objetivo para ser alcançado. O estrangeiro é aquele homem que tem a capacidade de se ver de fora e, por conseguinte, traz em si mesmo uma estranha liberdade: a escravidão do desejo de ser livre. Sob um olhar inquisidor, por parte da população do lugar onde ele está, ele é um estranho e, como consequência indelével, ele estranha a si mesmo, visto que não há clareza quanto à sua direção e à sua identidade.

Autonomear-se estrangeiro significa, portanto, ser do mundo, livre para ir por todas as direções. De resto, fica-nos, então, a dúvida, lançada por Kristevap "devemos admitir que nos tornamos estrangeiros num outro país porque já o somos por dentro?" (1994, p. 22). Talvez, desde que se considere que o que "somos por dentro" seja um ponto de 
vista produzido por um "olhar de fora". Mais do que uma simples visão de dentro ou de fora, interna ou externa ao ser estrangeiro, o que está em xeque, na verdade, é uma "visão de mundo". Dependendo de onde e para onde se direciona o olhar, certamente se têm visões diferentes; afinal, a maneira como se olha para as coisas, ou como as coisas são vistas, tem implicações epistemológicas e ontológicas sobre o ser estrangeiro, que, nesse acaso, se associa justamente ao oposto de Meursaul, personagem que encarna a falência do existir no romance $O$ estrangeiro, de Albert Camus.

Em nosso texto-musical, o eu-lírico afirma $E$ eu, menos estrangeiro no lugar que no momento, indicando que o estrangeiro é a discordância dos pontos de vista expostos por aquele cara e aquela. A oposição entre espaço e tempo talvez esteja relacionada à questão de não se sentir estrangeiro, ou menos estrangeiro, no lugar (Praia de Botafogo - Rio de Janeiro - Brasil), porém, sentir-se distanciado do momento, como índice de uma recusa. Nessa perspectiva, inferimos a questão política, pois, naquele momento, o Brasil experimentava sensações de liberdade. Havia poucos anos que o regime militar tinha acabado, havíamos tido a primeira eleição presidencial por voto direto (a última ocorrera em 1960, com a eleição de Jânio Quadros para a 
presidência), tudo isso distancia o eu-lírico do momento; principalmente após ouvir uma sucessão de discursos reacionários a favor da tortura, da descriminação racial, do comportamento machista, enfim, tudo o que transforma a experiência humana numa aventura degradada, sob a égide do despotismo e da capacidade destrutiva. O texto musical é uma denúncia de tudo quanto conspira contra a liberdade, e o gesto generoso da compreensão se constitui na tarefa mais importante pelo poeta.

Nesse sentido, a letra da música nos propõe um exercício de reflexão poética, no que tange à transformação daquilo que nos é familiar em exótico e daquilo que nos é exótico em familiar, especialmente sobre a ressignificação do que é ser estrangeiro na pós-modernidade. O texto nos conduz a um leque de opções capaz de descortinar a maneira como os homens refletem sobre a sua própria condição, além de nos levar a um exercício de reflexão sobre os estranhamentos dessas mesmas experiências sociais e sua intrínseca significação. Para muitos leitores, Caetano Veloso inspirouse no escritor franco-argelino Albert Camus (1913-1960), para a composição desta letra de música.

No entanto, observando-se os extremos, nenhum estrangeiro se compara ao estranho estrangeiro, de Camus. 
Mersault é, na verdade, um estrangeiro de si mesmo. Seu exílio interior o distancia tanto de seus compatriotas franceses quanto dos árabes, com os quais convive, na Argélia, à época uma colônia francesa. Demonstra uma indiferença pela vida, como um todo, que, por deixá-lo muito próximo ao niilismo, segundo Nietzsche, representa "a radical recusa de valor, sentido e desejabilidade" (1983, p. 379). Nesse sentido, o niilismo de Mersault não está atrelado tão somente ao fracasso da "crença nas categorias da razão", se pensarmos novamente em Nietzsche, mas também em função do espírito imbuído na época à qual a personagem pertence e o romance ocorre: Segunda Guerra Mundial. Paradoxalmente, o vazio interior que habita Mersault será preenchido por uma total indiferença ao mundo e à humanidade. Como vemos no último parágrafo do livro, nos momentos anteriores à sua execução, após alguma reflexão sobre o sentido da morte, a da mãe e a sua própria, chega à seguinte conclusão:

Como se esta grande cólera me tivesse limpo do mal, esvaziado da esperança, diante desta noite carregada de sinais e de estrelas, eu abria-me pela primeira vez à terna indiferença do mundo. Por o sentir tão parecido comigo, tão fraternal, senti que fora feliz e ainda o era. Para que tudo ficasse consumado, para que me sentisse menos só, faltava-me desejar que houvesse muito 
público no dia da minha execução e que os espectadores me recebessem com gritos de ódio. (CAMUS, 1982, p. 298)

Em verdade, não é o estrangeiro o ser indiferente à humanidade, é a própria humanidade que lhe é indiferente. Mas, para que não deixe o mundo, levando consigo essa sensação de indiferença, Mersault deseja ser ovacionado com gritos de ódio; afinal, o ódio o torna real, o ódio seria a demonstração de algum sentimento, e não a total indiferença. O curioso é que, a partir da morte da mãe, Mersault descobre-se e revela-se um estrangeiro, um órfão não só de pais como de país.

E aí habita o cerne de nossa discordância de que Caetano tenha-se inspirado no romance homônimo à letra de música, para a sua composição: o estrangeiro da música não é indiferente à humanidade; ao contrário, ele se indigna com o pensamento reacionário e conservador, ele não espera por gritos de ódios, mas por atos de empatia e solidariedade, e, após a indignação com o desmascaro do discurso, ele grita:

Singelo grito:

"O rei está nu"

Mas eu desperto porque tudo cala frente ao fato de que o rei é mais bonito nu 
"O rei está nu!" Esta frase, quando ouvida em qualquer parte do mundo, remete-nos um único significado: o sentido que nasceu a partir do conto "A roupa nova do imperador" (2012), do dinamarquês Hans Christian Andersen, em 1837, e também um dos contos mais famosos desse autor, ao lado de "O patinho feio" e "A pequena sereia".

O enunciado produzido por uma criança representa a expressão daquilo que é evidente, a realidade óbvia diante dos olhos que todos fingem não ver. O clássico conto narra a história de um vaidoso imperador que adora roupas novas. Sua vida é regida pela moda. Certo dia, aparecem, no reino, dois espertalhões que propõem fazer para o rei uma rara roupa: uma vestimenta que os tolos não conseguiriam ver, somente as pessoas inteligentes teriam a capacidade de vê-la e deslumbrá-la. Todos os habitantes do reinado, quando olharam para a roupa, não desejando se passarem por tolos, mesmo sem ver a tal vestimenta, elogiavam-na. Inclusive o próprio rei que passeia pelas ruas com um traje que todos fingem enxergar. Até que um menino, com toda a inocência de sinceridade do mundo, grita: "- 0 rei está nu!". E todos concluem que, se uma criança, com toda sua pureza, constatava que o monarca estava mesmo exposto em suas vergonhas, é que tudo naquele reino não passava 
de uma farsa. Os falsos tecelões desapareceram, levando consigo muito dinheiro, fios de seda e ouro. Meses depois, um viajante chegou à terra do rei vaidoso e, sabendo da história, informou que o mesmo golpe havia sido aplicado em outro pequeno reino. Dizem que ele ainda andava de nariz empinado e que eram grandes as hipocrisias. Afinal o rei é o "macho adulto branco no comando".

Mas eu desperto porque tudo cala frente ao fato de que o rei é mais bonito nu. Nessa passagem, o eu-lírico não se considerava mais tão estrangeiro. Sente-se maravilhado, e até vingado, por despertar para a realidade, por descobrir que a verdadeira identidade do poder está na hipocrisia e por se distanciar desse olhar. De fato, não é a nudez que é bela, mas o fato de o rei estar nu, desmascarado. Essa é a verdade que silencia todas as coisas. É índice-símbolo de um silêncio de espanto e de constatação. Observemos o jogo textual que Caetano faz com o verso É um desmacaro: o verso se encontra entre dois versos finalizados por dois pontos. Nesse sentido, ele representa uma função anafórica indicial a aquele cara e aquela, pois é o desmascaramento representado no discurso desses interlocutores; e, ao mesmo tempo, representa uma função catafórica indicial ao singelo grito (que também é um verso de valor catafórico), o 
desmascaramento é a consequência da reflexão do diálogo e a causa para se gritar $O$ rei está nu.

Atentemos, ainda, à escolha do adjetivo singelo que nos traz olhares semiótico-estilísticos diferenciados. O verso "O rei está nu" vem entre aspas, reforçando, no dizer bakhtiniano, o vezo polifônico deste texto musical. Nesse sentido, podemos entender singelo como índice da simplicidade da fala de uma criança, uma vez que ele reproduz a fala do menino do conto, ou como índice da descomplicação das ideias conservadoras de aquele cara e aquela, pois, como um cego às avessas, o eu-poético distingue o certo e o errado, de uma forma simples, singela. E a consciência de não estar preso a essas amarras reacionárias liberta o eu-lírico e o leva a seguir em frente:

E eu vou e amo o azul, o púrpura e o amarelo E entre o meu ir e o do sol, um aro, um elo

Observamos, então, índices do Tropicalismo de "Alegria, Alegria" que são facilmente identificados em "O estrangeiro", seja pelo reaproveitamento do verso Caminhando contra o vento, em Sigo mais sozinho caminhando contra o vento (cônscio de sua solidão na trajetória tropicalista) seja pela reafirmação do Eu vou, afora a presença das cores: Eu vou $e$ amo o azul, o púrpura e o amarelo (Por entre fotos e nomes) 
Os olhos cheios de cores) e do sol: E entre o meu ir e o do sol, um aro, um elo (No sol de quase dezembro.../ O sol se reparte em crimes.../ O sol nas bancas de revista/ $O$ sol é tão bonito...). Nossa associação é corroborada por Caetano Veloso, conforme podemos ver numa reportagem feita por O Estado de São Paulo: "[...] eu acho que Estrangeiro tinha mais referência à coisa do Tropicalismo" (apud LUCHHESI; DIEGUEZ, 1993, p. 271, grifo dos autores).

Tal declaração e Caetano Veloso só referencia nosso olhar polifônico deste texto musical, cuja polifonia não é marcada apenas por uso de aspas, mas pelo diálogo com outras músicas de sua autoria, principalmente as que estão inclusas neste mesmo disco. $O$ jogo de cores em E eu vou $e$ amo o azul, o púrpura e o amarelo está presente na música "Rai de cores", como veremos a seguir:

\begin{tabular}{|c|c|}
\hline Para a folha: verde & Para o bicho: verde \\
\hline Para o céu: azul & Para o bicho: branco \\
\hline Para a rosa: rosa & Para o bicho: pardo \\
\hline Para o mar: azul & Para o homem: azul \\
\hline Para a cinza: cinza & Para o homem: negro \\
\hline Para a areia: ouro & Para o homem: rosa \\
\hline Para a terra: pardo & Para o homem: ouro \\
\hline
\end{tabular}


Para a terra: azul

(quais são as cores que são

[suas cores de predileção?)

Para a chuva: prata

Para o sol: laranja

Para o carro: negro

Para a pluma: azul

Para a nuvem: branco

Para a duna: branco

Para a espuma: branco

Para o ar: azul

(quais são as cores que são
Para o anjo: azul

(quais são as cores que são [suas cores de predileção?)

Para a folha: rubro

Para a rosa: palha

Para o ocaso: verde

Para o mar: cinzento

Para o fogo: azul

Para o fumo: azul

Para a pedra: azul

Para tudo: azul

(quais são as cores que são

[suas cores de predileção?)

Essa música é a segunda faixa do disco Estrangeiro, ou seja, vem logo após a letra com a qual estamos trabalhando. "Rai das cores" é uma homenagem à plasticidade das próprias cores (e, por extensão, à pintura), correlacionandoas com a realidade a partir da expressão subjetiva de um pintor. Caetano, mais uma vez, mescla cores e sons, como um desejo de fundir outras duas faces de si mesmo: compositor e pintor. Rai (Raï, no original francês) é o nome dado à mistura de ritmos musicais de origem argelina (a sinestesia 
novamente se faz presente). Lucchesi e Dieguez nos trazem um bom esclarecimento sobre essa letra de música:

A pergunta (verso-refrão "quais são as cores que são suas cores de predileção?"), extraída de uma entrevista de Tônia Carrero, serve para desdobrar o próprio eu: o azul, cor de predileção de Tônia, é repetida junto aos símbolos constitutivos de sua poética: "mar" (plano místico), "terra" (espaço), "ar" (o voo libertário do pássaro), "anjo" (plano místico), "pedra" (o talismã = eu). A música transfere para a letra, singela, um clima de alegria, sentimento com que eu se entrega à existência. (1993, p. 206, grifos dos autores)

No entanto, a letra pode ser outro recurso indireto para Caetano falar de si mesmo. Notamos, claramente, que para o eu-poético o azul é tudo, todas as coisas, por isso é a primeira cor a ser amada (Eu vou e amo o azul, o púrpura e o amarelo). Inferimos, então, uma possibilidade de leitura: azul é a cor do orixá de Caetano Veloso, Oxóssi, e também é algo já explorado pelo compositor, como podemos aferir, nessas duas estrofes de "Lua de São Jorge":

Lua de São Jorge

Lua deslumbrante

Lua de São Jorge

Lua soberana

Azul verdejante

Calda de pavão

Nobre porcelana

Sobre a seda azul

$[\ldots]$ 
Merleau-Ponty ressalta que:

Os sons podem interferir nas tonalidades das cores. Assim, um som intenso as torna mais vivas, a interrupção do som as faz vacilar, um som mais baixo torna o azul mais escuro ou mais profundo.

A captação das vibrações depende da capacidade do aparelho sensitivo. $\mathrm{O}$ que nos circunda tem forma, cor, movimento etc. porque possuímos sentidos adequados para captar e estruturar mentalmente a realidade objetiva segundo essas características. (2006, p. 234)

Nesse sentindo, observamos, mais uma, vez um olhar sinestésico para as cores e reafirmamos que para o eu-lírico o azul é tudo, é símbolo do ato, enquanto o púrpura, pela natureza vibrante da cor, é símbolo do que poderia vir a ser: a força, a pujança, a potência, buscas as quais não podemos definir se são desejadas ou temidas, pois representam o possível, o subjacente, como índice de uma espécie de virtualidade. Notemos, ainda, que púrpuro/a é uma referência constante nesta letra. E o amarelo que é a cor do sol seria índice-símbolo de consciência, pois, a verdade é aqui revelada e representada pelo rei nu. Além disso, o sol traz à tona a luz que ilumina tudo que ficou oculto durante a noite, logo é símbolo do despertar da consciência, depois do pesadelo: Em que passara passa passará um raro pesadelo. 
É importante observar que, nessas duas letras de música, Caetano atribui ao sol a cor laranja: Para o sol: laranja e o sinestésico À áspera luz laranja.

Então, após o eu-lírico ter um quase deslumbre espectral newtoniano, ele conclui seu pensamento $-E$ entre o meu ir e o do sol, um aro, um elo - de forma bem simples: palavras curtas: monossílabos e dissílabos pequenos. A substantivação do verbo ir (reafirmando o Eu vou, independentemente do tempo verbal) e a união do e o (ir) do sol estabelecem uma relação cíclica, um aro, e, mesmo que não seja uma circunferência perfeita, não deixa de ser um elo, além se estabelecerem uma rima bem peculiar: a coincidência apenas na vogal átona final [u] e a troca das alveolares [r] e [l], cuja expressividade, conforme observação de Martins: "o deslizar, o fluir, o rolar, podem exprimir-se pelas constritivas laterais [I], [Ih] e pelas vibrantes [R] e [r]" (1997, p. 36). Assim, o desejo de seguir em frente, de fluir, ultrapassa as barreiras, portanto, o compositor opta pelas palavras curtas, como índices-símbolos de demonstração da facilidade do que é deixar para trás aquilo que é pesado, é fardo e é cansativo. $\mathrm{O}$ sol que é tão bonito e foi testemunha do discurso conservador que ouvira pela manhã, afinal, o sol também refletia os dentes quase-não- 
púpura da menina, surgirá no novo amanhecer, revestindo eu-lírico e novas esperanças, mesmo tendo consciência da imperfeição do mundo:

("Some may like a soft brazilian singer

But I've given up all attempts at perfection ${ }^{7 ”}$ )

Esses versos, que representam a voz de Bob Dylan, entre parêntesis, como uma observação final, tenham talvez uma dupla significação: 1. Mostrar a grande admiração que Caetano tem por Bob Dylan, afinal já o citou em uma de suas composições anterior a esta: $E$ não nos interessa $a$ tripe cristã de Dylan Zimmermann ("Ele me deu um beijo na boca"), e vale lembrar que, no CD Circuladô ao Vivo (1992), Caetano regrava "Jokerman", uma composição espetacular de Bob Dylan; e 2. Resumir o conteúdo do pensamento do eu-lírico apresentado ao longo deste texto musical.

Assim, a desistência de atingir a perfeição torna-se índice da forma como as contrariedades provenientes da sensação de mal-estar causada pela civilização/sociedade pósmoderna também contribuem para a transformação do eupoético num estrangeiro; pois, mesmo viajando pelos mais

7 Bob Dylan, no encarte do seu Bringing It All Back Home (1965) escreve: "my songs're written with the kettledrum in mind / a touch of any anxious color / unmentionable, obvious, an' perhaps some may like a soft brazilian singer / but I have given up at making any attempt at perfection" cuja tradução livre seria: "minhas músicas foram escritas com o timbale na mente / um toque de qualquer cor ansiosa / impronunciável, óbvio e, talvez,/ alguns podem gostar da suavidade de um cantor brasileiro,/ mas eu desisti de atingir a perfeição". 
diferentes e inusitados espaços, especialmente se estiver fora de sua área de conforto, não encontra a extensão de si mesmo; por isso, conforme dissemos anteriormente, ele se torna um estrangeiro, um ser livre que não se sente preso a nada, e sobrevivência é sinônimo de deslocamento. Dessa forma, o eu pode ultrapassar fronteiras limítrofes e não limítrofes, e por que não, já que é livre para tal?

Esse pensamento levou Caetano a unir-se a Peter Sherer e Arto Lindsay, para a produção de Estrangeiro, cujo resultado é um disco com excelente qualidade sonora que satisfaz qualquer público, seja nacional seja internacional, sem que houvesse necessidade da renúncia de Caetano a nenhum de seus princípios. Ao contrário, isso revalidou os ideais de inclusão que foram os alicerces do Tropicalismo. Lucchesi e Dieguez apresentam uma excelente leitura sobre a produção deste disco:

Por que não unir aos ritmos brasileiros os recursos técnicos estrangeiros, se isto resulta num produto ainda mais qualificado? Por outro lado, quem determinou que a linguagem da arte deva viver confinada? A percepção de que, para além da sociedade brasileira, existe uma sociedade planetária [que] permite a Caetano o estado de permanente disponibilidade, de abertura, o que só the enriquece o potencial musical, na razão direta de uma expressão capaz de integrá-lo de modo mais pleno no mundo, 
em outras culturas, a fim de, cada vez mais intensamente, incorporar ao seu processo de criação elementos lítero-poéticos que contribuam para manter a sua obra nos padrões excelência que sempre se impôs. (1993, p. 205)

Desde "Tropicália", "Baby", "Podres poderes" etc., Caetano está antenado com os problemas sociais, políticos e econômicos pelos quais o Brasil passa e usa sua música como uma forma de denúncia daqueles que deveriam ser os responsáveis para gerenciar a solução desses problemas e de pedido de justiça pelos meninos e meninas abandonados pelas ruas dos grandes centros urbanos que, com poucas opções, acabam enveredando no império da marginalidade que, infelizmente, se institucionalizou em nossa sociedade. É essa a canção-denúncia de Estrangeiro que também dialoga com "Os outros românticos", outra canção-denúncia do mesmo disco:

Eram os outros românticos, no escuro

Cultuavam outra idade média, situada no futuro

Não no passado

Sendo incapazes de acompanha

A baba Babel de economias

As mil teorias da economia 
Recitadas na televisão

Tais irredutíveis ateus

Simularam uma religião

E o espírito era o sexo de Pixote, então

Na voz de algum cantor de rock alemão

Com o ódio aos que mataram Pixote a mão

Nutriam a rebeldia e a revolução

E os trinta milhões de meninos abandonados do Brasil

Com seus peitos crescendo, seus paus crescendo

E os primeiros mênstruos

Compunham as visões dos seus vitrais

E seus apocalipses mais totais

E suas utopias radicais

Anjos sobre Berlim

"O mundo desde o fim"

E no entanto era um SIM

E foi e era, e é, e será sim

A canção de Caetano também faz barulho, não só pela guitarra distorcida de Arto Lindsay, como também pela 
crítica aos poetas e escritores românticos, que, com sua visão ufanista, criam sempre numa salvação utópica; entretanto, urge uma ação imediata, ou, pelo menos o início de uma que transforme esta realidade concreta e atual. Caetano cita em "Os outros Românticos", que cultuavam outra idade média, situada no futuro, utopias radicais que só serão, ou foram, dissecadas em "O estrangeiro":

É chegada a hora da reeducação de alguém

Do Pai, do Filho, do Espírito Santo, amém

O certo é louco tomar eletrochoque

O certo é saber que o certo é certo

O macho adulto branco sempre no comando

E o resto ao resto, o sexo é o corte, o sexo

Reconhecer o valor necessário do ato hipócrita

Riscar os índios, nada esperar dos pretos

Caetano não se opõe ao romantismo de uma geração que quis mudar o mundo, ao usar o pronome outros, na verdade, leva-nos a crer que se inclui nesse grupo, porém, sob outro olhar, não o utópico, mas aquele cujas bases se assentam na coletividade, na transformação, e não subordinado a um procedimento de cunho messiânico. 
A utopia radical de "Os outros Românticos" reflete a tríade da organização católica: Tradição, Família e Propriedade, não para tomar um partido religioso, mas para apontar as deficiências da visão de cada um. Em "O estrangeiro", ele desmascara o discurso proto-facista (ou seria procto-facista?) que defende a tortura como aceitável em alguma situação, que defende a criminalização e até a internação forçada de qualquer um que seja considerado como louco pela sociedade, submetendo ao choque. Estar à subserviência do "Batalhão de Choque", como Caetano denunciará, anos depois, na música "Haiti". Caetano exercita o olhar de estranhamento fundamental para a compreensão das redes de pensamento que ainda dominam a sociedade atual, não para demolir alguma, mas para abrir espaço para novas afirmações, e usando, mais uma vez, o recurso do poliptoto: E no entanto era um sim/ E foi e era e é e será sim.

Não nos propomos estender uma análise dessa letra de música. Nosso objetivo era apenas ratificar a presença de um discurso polifônico neste disco, além de não só mostrar que algumas letras de músicas dialogavam entre si, como também de apresentar semelhanças em suas estruturas: o uso de parêntesis; o uso de citações, em "Os outros 
românticos", temos "O mundo desde o fim", que é o título do livro de Antônio Cícero e cujo teor está intimamente ligado a essas suas letras de música, pois dialogando com Descartes, Kant, Hegel, Heidegger e Marx, $O$ mundo desde o fim discute os conceitos de modernidade e racionalidade no ocidente. E revela, por meio de perspectivas inesperadas e enriquecedoras, não apenas o núcleo da modernidade, mas o olhar do homem sobre ela e nela.

Finalizando, porém não concluindo, pois existem inúmeras possibilidades ainda a serem exploradas, neste texto musical, podemos dizer que a letra se divide em três partes: a primeira estaria relacionada à questão espaçomomento: o nascer do dia, na Praia de Botafogo; a segunda estaria relacionada ao motivo da criação deste texto: a audição das falas que retratavam um discurso reacionário; e a terceira estaria ligada ao próprio eu-poético: a negação dessas utopias radicais e a certeza de que precisa ir em frente, não vendo o mundo em preto (o terno do homem) e branco (os dentes da menina), índices-símbolos do pensamento reacionário, mas com todas as cores que a palheta da natureza puder oferecer, afinal, como o próprio Caetano canta, na belíssima composição "Sorte", de Celso Fonseca e Ronaldo Bastos: 


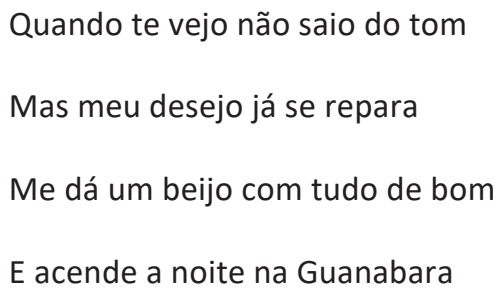

\section{REFERÊNCIAS}

ANDERSEN, Hans Christian. A roupa nova do imperador. São Paulo, Scipione, 2012.

CAMUS, Albert. Estado de sítio: o estrangeiro. São Paulo: Abril Cultural, 1982.

CIVITA, Victor (Ed.) (1976). Gênios da pintura. 2. ed. São Paulo: Abril Cultural, 1973.

CUNHA, Antônio Geraldo da. Dicionário Etimológico Nova Fronteira da Língua Portuguesa. 2. ed. 9. impr. Rio de Janeiro: Nova Fronteira, 1997.

DUARTE, Paulo Sérgio. O que Seurat será?. In: NOVAES, Adauto (Org.). O olhar. São Paulo: Companhia das Letras, 1988.

FRANCHETTI, Paulo; PÉCORA, Alcyr. Caetano Veloso. Literatura Comentada. São Paulo: Editora Abril, 1982.

FREUD, Sigmund. O infamiliar. Belo Horizonte: Editora Autêntica, 2019.

HOBBES, Thomas. Behemoth ou o Longo Parlamento. Tradução de Eunice Ostrensky. Belo Horizonte: UFMG, 2001.

HOUAISS, Antônio; VILLAR, Mauro de Salles. Dicionário Houaiss da Língua Portuguesa. Rio de Janeiro: Objetiva, 2009.

KRISTEVA, Julia. Estrangeiros para nós mesmos. Rio de Janeiro: Rocco, 1994.

LAPA, Manuel Rodrigues. Estilística da Língua Portuguesa. 3. ed. São Paulo: Martins Fontes, 1991.

LÉVI-STRAUSS, Claude. Tristes trópicos. Lisboa: Edições 70, 1979.

LUCHESI, Ivo; DIEGUEZ, Gilda K. Caetano, por que não?: uma viagem entre a aurora e a sombra. Rio de Janeiro: Leviatã, 1993. 
MARTINS, Nilce Sant'Anna. Iniciação à Estilística. 2. ed. São Paulo: T. A. Queiroz Editora, 1997.

MERLEAU-PONTY, Maurice. Fenomenologia da Percepção. 3. ed. São Paulo: Martins Fontes, 2006.

MONTEIRO, José Lemos. A Estilística. São Paulo: Ática (Fundamentos), 1991.

NIETZSCHE, Friedrich. Obras incompletas. São Paulo: Abril Cultural, 1983.

REI, Claudio Artur O. Etimologia das Figuras de Linguagem. Monografia de conclusão de graduação. Rio de Janeiro: UERJ, 1989.

REI, Claudio Artur O. A Palavra Caetana: estudos estilísticos. Rio de Janeiro: UERJ. (Dissertação de Mestrado), 2002.

RÓNAI, Paulo. Dicionário Universal Nova Fronteira de Citações. Rio de Janeiro: Nova Fronteira, 1985.

SPITZER, Leo. La Enumeración Caótica en la Poesía Moderna. Buenos Aires, 1945.

VELOSO, Caetano. Estrangeiro. Brasil: Philips, 1989. 1 CD.

VELOSO, Caetano. Letra só: sobre as letras. Organização e notas de Eucanaã Feraz. São Paulo: Companhia das Letras, 2003.

Claudio Artur O. Rei é Doutor e Mestre em Língua Portuguesa pela UERJ, instituição na qual também cursou a graduação e a especialização. Professor do Ensino Médio desde 1990, na rede particular, professor do Ensino Fundamental desde 1994, na rede pública, e professor do Ensino Superior, na Universidade Estácio de Sá, de 2000 até 2017, com a função de professor adjunto. Desenvolve pesquisas na área de Estilística, com subsídios em Semântica e Semiótica voltada para uma modalidade funcional em que se discutem as escolhas lexicais, a partir das variantes eleitas a serem aplicadas. Participa, também, de congressos, nacionais e internacionais, nos quais expõe seus trabalhos e resultados de suas pesquisas. Também acumulou a função de coordenador do curso de Letras, na UNESA, por seis anos, de 2010 a 2016. Membro do Grupo de Pesquisa SELEPROT - Semiótica, Leitura e Produção de Texto da UERJ. Email: arturrei@uol.com.br 